\title{
A capacidade de regulação estatal na Argentina
}

\section{Oscar Oszlak e Ruth Felder}

Ano 51

Número 1

Jan-Mar 2000

\section{Introdução}

A reforma do Estado, iniciada na grande maioria dos países latinoamericanos no final dos anos 80, possui duas fases claramente diferenciadas como característica. Observadas retrospectivamente e talvez de forma simplificada, têm sido denominadas primeira e segunda fases da reforma, embora, na prática, tratem-se de dois momentos quantitativa e qualitativamente diferentes.

A primeira fase se caracterizou pela redução do aparato estatal mediante a transferência a terceiros (empresários privados, ONGs, governos subnacionais e fornecedores) da responsabilidade de produzir determinados bens e serviços, tanto para usuários da sociedade quanto para o próprio Estado. Além da privatização, descentralização e terceirização, que foram seus principais instrumentos, essa etapa também incluiu a desregulação de várias atividades econômicas (controles de preços, intervenções equilibradoras nos mercados, mecanismos de promoção). No caso argentino, as transformações tiveram um caráter veloz e profundo, traduzindo-se na eliminação de um segmento significativo da estrutura institucional do Estado, de sua dotação de pessoal e, em última instância, de alguns de seus papéis tradicionais ${ }^{1}$.

Quando se observa que, convencionalmente, a atividade estatal se manifesta através da produção de bens, da prestação de serviços e da regulação da atividade sócio-econômica, fica claro um "esvaziamento", do domínio funcional do Estado, parcialmente compensado pelos novos papéis assumidos: ao invés da produção direta dos bens e serviços, o Estado tenta regular as condições de prestação dessas mesmas funções,

\author{
Oscar Ozlak, \\ doutor em \\ Ciências Políticas \\ pela Universidade \\ de Berkeley. \\ Doutor em \\ Ciências Econô- \\ micas, diretor \\ do programa de \\ mestrado em \\ Administração \\ Pública e pesqui- \\ sador do Conse- \\ lho Nacional \\ de Pesquisas \\ Científicas e \\ Técnicas da \\ Universidade de \\ Buenos Aires. \\ Ruth Felder, mes- \\ tre em Adminis- \\ tração Pública, \\ licenciada em \\ Ciências Polí- \\ ticas, professora \\ assistente da \\ Faculdade \\ de Ciências \\ Econômicas na \\ Universidade de \\ Buenos Aires \\ Traduzido por \\ Maria Mercedes \\ Mourão
}


que foram transferidas a outros agentes sociais, assumindo também, em certos casos, responsabilidades de promoção e financiamento.

Cabe esclarecer que as funções regulatórias que substituem as diretamente produtivas, são diferentes das desativadas pelas políticas de desregulação mencionadas acima. A diferença essencial entre umas e outras é o caráter público dos bens ou serviços envolvidos. Com efeito, a nova regulação pretende abranger as relações entre o Estado, os prestadores e os usuários, quanto às condições em que os novos operadores prestam serviços públicos. Por outro lado, as regulações suprimidas no marco da reforma estatal apontavam para a aplicação de regras de jogo segundo as quais o Estado tentava preservar ou corrigir determinados desequilíbrios econômicos ou sociais, como no caso do estabelecimento da base de preços; do fornecimento de certos insumos críticos; do uso de estoques de intervenção para regular os mercados; da fixação da paridade cambial, do salário mínimo ou da taxa de juros bancária. Nesses casos, existe um interesse público, mas não um serviço público afetado.

Existe, ainda, outra área importante de intervenção estatal vinculada à função reguladora, embora de natureza diferente da anterior. Trata-se das funções de habilitação, controle e inspeção de estabelecimentos privados e públicos dedicados à produção e comercialização de diversos bens de consumo (alimentos, medicamentos) ou à prestação de determinados serviços (i.e. de saúde, educacionais, recreativos, culturais, de segurança) em aspectos relativos às condições de produção, qualidade dos bens ou serviços, observação de normas de moralidade pública etc.

Apesar do Estado nacional não ter se desvinculado destas funções, existem indícios de que o maciço desmantelamento de seu aparato institucional durante a primeira fase da reforma, poderia ter comprometido, em parte, sua capacidade de exercer plenamente as funções regulatórias irrevogáveis e fundamentais que lhe cabe desempenhar nestas áreas. Na medida em que a redução estatal se manifestou na redução de pessoal capacitado (via aposentadorias antecipadas e demissões voluntárias, ou na diminuição de recursos para infra-estrutura, bens e serviços não pessoais), pode-se ter produzido uma crescente deformidade na função de produção destes serviços, o que alterou sua prestação eficaz. As freqüentes denúncias sobre comercialização de medicamentos não autorizados ou falsificados, alimentos em deplorável estado de higiene, acidentes produzidos pela falta de controles oportunos, dentre muitos outros exemplos, evidenciam a debilidade institucional existente para prevenir tais situações.

Com estas notas introdutórias, procuramos contextualizar a questão da regulação estatal dentro do escopo das mudanças produzidas na primeira fase da reforma do Estado. A intenção da segunda fase é a de passar de uma evidente situação de menos Estado a uma situação de melhor 
Estado. Seus objetivos apontam muito na direção do interior do aparato institucional do que na direção da sociedade ou dos níveis subnacionais do Estado. Propõe-se adequar a distribuição de papéis entre as diversas áreas da administração e da hierarquização dos recursos humanos em função de critérios de eficácia, eficiência e economia na gestão (Rodríguez, 1996).

Essa "introversão" da reforma é uma tarefa pendente. O valor retórico e simbólico de seu enuncia do não seria questionável se a intencionalidade política manifestada se apoiasse em uma séria avaliação das possibilidades de alcançar os objetivos almejados. Nesse sentido, e no que diz respeito à regulação, a primeira reforma deixou como pendência a criação e fortalecimento da principal contrapartida do processo privatizador: o aparato institucional responsável pela regulação das empresas e serviços privatizados. Essa tarefa deveria ter correspondido a essa primeira etapa reformadora e sua execução deveria ter sido simultânea ou, inclusive, prévia à decisão de privatizar. Agora, em condições de negociação muito mais difíceis em função do extraordinário poder adquirido pelos novos donos do poder econômico, a tarefa pendente tem sido encomendada aos responsáveis pela segunda reforma.

Neste trabalho analisaremos a capacidade institucional disponível no Estado argentino para enfrentar, de maneira eficaz, suas responsabilidades regulatórias no campo da prestação de serviços públicos privatizados. Diferente de muitos trabalhos que recentemente abordaram a questão, não tentaremos avançar na conceitualização da regulação estatå nem na análise de seus instrumentos técnicos ${ }^{3}$. A extensa literatura disponível nos exime de seu tratamento, ainda que sua referência possa justificar-se em alguns trechos do trabalho.

Ao contrário, nossa análise procurará empregar uma abordagem sistemática para analisar os déficits de capacidade institucional observáveis nos organismos do Governo argentino que cumprem funções regulatórias no contexto do Estado pós-ajuste. O objetivo é refletir sobre os desafios institucionais que pressupõem essa substituição dos papéis tradicionais de produção, financiamento e prestação, por outros de regulação e controle. Interessa-nos encontrar algumas respostas a questões, tais como: o que ganha ou perde o Estado ao transferir responsabilidades de produção ou prestação direta, que processos se desencadeiam nos planos do poder e da distribuição da renda, e até que ponto se pode revertê-los mediante ações de regulação.

Para isso, o texto se concentrará na relação que deveria existir entre as responsabilidades da regulação e a capacidade institucional disponível. Isto implica examinar de maneira sistemática questões relativas: 
- às regras de jogo que governam as relações entre os agentes envolvidos na gestão reguladora;

- à natureza das redes interinstitucionais que se estabelecem entre si;

- aos arranjos estruturais e funcionais que se criam para que a função reguladora seja cumprida;

- às políticas de incentivos e sanções estabelecidas para aqueles que devem desempenhar tais funções;

- aos recursos materiais e humanos disponíveis; e

- às capacidades individuais que se requerem para que o papel regulador seja cumprido a contento.

Também, contrariamente a outra tendência observável nos estudos neste campo, não serão analisados casos relacionados a esta ou àquela instituição, serviço ou área específica de regulação. Não obstante, este trabalho utilizará casos já estudados para obter evidências que ilustrem os aspectos que se pretende abordar.

\section{Considerações conceituais}

Resolvida a questão de sua dimensão, emerge agora, mais nitidamente, um conjunto de questões ligadas à redefinição do papel do Estado após o processo de reforma. No debate suscitado, isso envolve desde pontos de vista de alto grau de generalidade e abstração (i.e. a materialização de um modelo de boa sociedade segundo o qual o Estado, o mercado e a sociedade civil ocupariam por fim os espaços adequados que correspondem a cada um) até questões mais instrumentais, tais como o desenho das políticas, mecanismos e recursos que consigam efetivar esse novo papel.

Existe um amplo consenso em assinalar que a transformação do Estado de produtor em regulador é um dos traços mais destacados da redefinição do seu papel. Apesar do fato de que, antes dos processos de reforma, os Estados desenvolviam amplas tarefas de regulação, as reformas produzidas tendem a redefinir os conteúdos dessa função. No entanto, na etapa anterior, a regulação implicava na existência de normas setoriais e territoriais em matéria de benefícios fiscais, controles de preços ou licenças de importação entre outros, e agora, as atuais atividades de regulação e controle se orientam à estrutura dos mercados, aos esquemas tarifários, aos compromissos de investimento, à qualidade dos produtos e serviços, à segurança dos usuários e de terceiros e ao cumprimento dos contratos. Trata-se de modalidades orientadas a controlar e encaminhar, por meio de instrumentos legais e administrativos, atividades que, embora geralmente desenvolvidas por agentes privados, têm grande 
impacto público. A regulação supõe um processo sistemático e contínuo, levado a cabo habitualmente pelas agências especializadas, mediante o qual se exigem ou se prescrevem certas atividades ou condutas por parte de agentes privados ou públicos.

Falar de Estado regulador supõe fazer referência a um Estado que:

"pretende proporcionar respostas específicas a problemas circunscritos, respeitando, na medida do possível, as lógicas de ação dos sistemas regulados" (Majone e La Spina, 1993).

Essas formas de intervenção supõem uma relação entre o próprio Estado, os agentes privados passíveis da regulação (em geral empresas privadas fornecedoras de bens e/ou serviços críticos) e os receptores destes bens ou serviços, tanto usuários e clientes quanto cidadãos em geral.

Embora essas definições abranjam um grande leque de possíveis áreas de ação, muitas das quais estiveram historicamente sujeitas à regulação estatal, como no caso do controle da produção e comercialização dos alimentos e medicamentos, da previdência social ou da proteção ambiental, o debate sobre o Estado regulador na Argentina está estreitamente associado à política de privatização de empresas públicas, provavelmente o instrumento mais visível durante a primeira etapa da reforma do Estado, caracterizada pela urgência de abrir mão da gestão destas empresas, eliminando um conjunto de problemas associados ao seu funcionamento.

A privatização favoreceria, ao menos em termos teóricos, uma definição mais precisa das tarefas a cargo do Estado por meio de uma clara divisão do trabalho, que permite efetivar as responsabilidades, já que enquanto os proprietários e agentes privados têm apenas que tentar maximizar as utilidades, o Estado deve ocupar-se em alcançar uma maior eficiência na atribuição (Torre e Gerchunoff, 1988). Dessa forma, seu papel é menos confuso do que quando realizava simultaneamente as tarefas de produtor, regulador e avalista do acesso aos serviços. Definições desse tipo trazem à tona a necessidade de alcançar um equilíbrio adequado entre a rentabilidade empresarial e as garantias face às falhas de mercado ${ }^{5}$ e aos efeitos potencialmente frágeis da lógica mercantil.

$\mathrm{Na}$ Argentina, a ordem de prioridades que caraterizou a primeira etapa de reforma do Estado (e o processo de privatização de empresas públicas dentro dela) adiou a criação e o fortalecimento do aparato institucional que deveria atuar como interlocutor dos prestadores privados, mediador entre estes e os usuários e/ou avalista do interesse público, em aberta contradição com os critérios usualmente aceitos na matéria, que recomendam a sanção dos marcos regulatórios e a criação das agências correspondentes antes de iniciar os processos de privatização. Como 
assinalamos anteriormente, ao deixar pendentes essas tarefas, as margens de ação para efetivá-las ficam notoriamente delimitadas legalmente, pelo que estabelecem os contratos de transferência dos serviços e, politicamente, pelo aumento da capacidade de exercer pressão dos setores econômicos encarregados desses serviços.

Nos últimos anos, dentro de um conjunto de questionamentos cada vez mais intensos aos postulados ideológicos do Estado mínimo, ocorrerem situações de conflito relacionadas à prestação e ao controle dos serviços ${ }^{6}$ que colocaram em relevo a natureza centralizadora da regulação deste tipo de atividade ${ }^{7}$. No entanto, a preocupação generalizada com o controle dos serviços públicos não se tem traduzido até o momento em uma política sistemática de fortalecimento da institucionalidade regulatória ${ }^{8}$.

As crescentes demandas no que diz respeito ao fortalecimento da regulação estatal de serviços públicos tornam-se indiscutíveis em nível de generalidade do seu contexto. Requerem, no entanto, uma análise mais minuciosa do conjunto de aspectos e opções do processo regulatório. Ao contrário de modelos que apresentam, em termos teóricos, as características, vantagens e desvantagens de possíveis técnicas de regulação, o ponto de partida deste trabalho é o esquema institucional existente para refletir sobre a capacidade disponível no Estado para assumir, de maneira eficaz, suas responsabilidades regulatórias no campo da prestação de serviços públicos.

Falar de serviços públicos exige uma primeira tomada de posição com relação ao tema. Implica assumir que persiste a responsabilidade estatal pela garantia de regularidade, uniformidade e continuidade dos serviços, independentemente da pessoa jurídica que esteja a cargo da gestão empresarial. $\mathrm{O}$ que supõe então que a garantia de um acesso equiitativo às redes de serviços, a harmonização entre os diferentes operadores, bem como o controle dos preços e as normas técnicas de qualidade devem ser objeto de regulação (López, 1997). Não é essa a posição de autores como Mairal (1993) que consideram que a privatização das redes de serviços significa passar da tradicional teoria do serviço público, desenvolvida na Europa continental, a um modelo mais próximo do public utility (utilidade pública) do direito norte-americano e inglês, ou seja, do serviço público como atividade estatal delegada aos particulares, ao serviço público como atividade privada regulamentada pelo Estado.

A mudança no plano da gestão que presume a substituição dos tradicionais papéis estatais de produção, financiamento e prestação pelos papéis de regulação e controle é apenas uma parte da redefinição das relações entre Estado e sociedade. Envolve, ainda, processos menos visíveis, porém não menos importantes. Por meio da reflexão em torno das 
características da institucionalidade regulatória poderiam ser encontrados alguns elementos para responder a questões, tais como o que ganha e perde o Estado ao transferir responsabilidades de produção ou prestação direta; quais são os processos de redistribuição do excedente social e dos recursos de poder, e até que ponto é possível revertê-los por meio de ações de regulação ${ }^{9}$.

Como assinalamos, a regulação da prestação de serviços públicos privatizados supõe uma modalidade de intervenção estatal segundo a qual as relações entre prestadores e usuários é intermediada pelas ações do Estado destinadas a proteger o interesse público envolvido e, desta maneira, o dos consumidores, usuários ou beneficiários. Na Figura 1 se representam os agentes que participam nas relações triangulares assim criadas e a natureza dos vínculos que estabelecem entre si. Em cada vértice do triângulo têm lugar diferentes processos que merecem ser examinados separadamente. Por sua vez, também as relações entre os vértices podem ser de grande importância para a análise ${ }^{10}$.

\section{Figura 1: Prestação, Consumo e Regulação}

\section{Agentes e Processos}

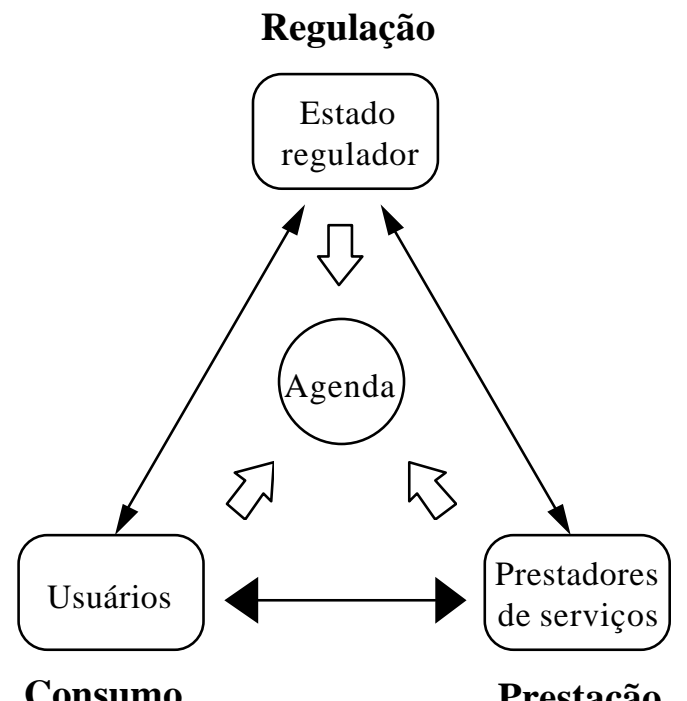

Os agentes identificados são o Estado regulador, os prestadores de serviços e os usuários. No vértice do Estado, decidem-se questões relativas ao âmbito da regulação, aos aspectos que abrangem e seus alcances, aos critérios de aplicação, aos marcos jurídicos e aos mecanismos 
institucionais a serem empregados para garantir sua vigência. No vértice da prestação, os prestadores, dentro do marco regulador estabelecido, adotam políticas relativas aos volumes dos serviços, aos tipos de usuários, às tecnologias a serem empregadas, aos custos e preços, aos investimentos necessários, à introdução de novos produtos e às estratégias para ganhar novos mercados, estender as concessões ou contrabalançar a ação reguladora. No vértice do consumo decide-se, sempre que possível, a utilização ou não dos serviços, os eventuais substitutos a serem empregados (i.e. gás por eletricidade, transporte ferroviário por transporte automotor), a frequiência, o alcance da utilização dos serviços, as táticas de free riders (acesso à redes, viagens sem bilhetes) e as estratégias individuais, familiares ou empresariais para enfrentar o custo dos serviços.

É possível analisar as relações que mantêm os agentes localizados nos vértices do triângulo. No vínculo regulação/prestação, os problemas centrais que se colocam são, por exemplo, os da capacidade institucional, legitimidade e poder coercitivo dos órgãos regulatórios para exercer seu papel. Isso inclui, entre outras coisas, conhecer com precisão o significado de regulamentar; como se define o papel estatal neste aspecto; com que alcance; como salvaguardar o interesse público neste sentido; que problemas de captura burocrática suscitam ou qual é a efetividade dos recursos de coerção e legitimidade do Estado, com relação aos de informação e recursos materiais que manejam as empresas e nos quais baseiam seu poder relativo.

No vínculo prestação/consumo, as partes posicionam-se com relação a questões, tais como o grau em que os serviços prestados satisfazem as necessidades dos usuários; a medida em que a prestação discrimina usuários (por exemplo, no que diz respeito ao alcance geográfico); os critérios de rentabilidade face aos investimentos necessários para seu fornecimento; o caráter razoável dos preços ou tarifas e os padrões de comparação; a incidência das tarifas sobre o orçamento dos usuários e o grau em que alteram preços relativos, afetando a eqüidade distributiva e contribuindo com o empobrecimento de certos setores etc.

Finalmente, na relação regulação/consumo verifica-se qual é a medida em que o interesse dos usuários fica protegido; qual é a efetividade do papel estatal; quanta legitimidade ganha ou perde o Estado no exercício de sua função reguladora; até que ponto os excessos no custo dos serviços não são equivalentes ao déficit das empresas públicas agora privatizadas, representando, em conseqüência, um tipo diferente de transferência, via preços, que compensa uma distribuição "às cegas" via déficit.

De todas as relações e processos previamente enumerados, os que interessam principalmente para o presente trabalho são os que ocorrem no "vértice" da regulação e nos vínculos entre regulação e prestação. 
Esses constituem nosso objeto primordial de análise, uma vez que a densi-

dade e orientação dessas interações refletirão, em última instância, a capacidade institucional do Estado para cumprir eficazmente seu papel regulador. Não obstante os outros vértices e suas inter-relações configuram as dimensões analíticas que, ou explicam parcialmente o déficit de capacidade institucional existente ou proporcionam informação contextual imprescindível para compreender esse déficit.

\section{Regras de jogo}

A definição dos objetivos e prioridades da regulação estatal pareceria ser um ponto de partida ideal para podermos determinar os arranjos interinstitucionais requeridos, os esquemas organizados de forma apropriada, os recursos necessários e demais variáveis associadas à capacidade institucional para exercer funções regulatórias de maneira eficaz. Porém, esse marco normativo nem sempre permite explicitar as regras de jogo que deveriam governar as relações entre as partes envolvidas no vínculo regulação/prestação.

Parte do êxito da regulação está associada, precisamente, com a clareza de tais regras. Por exemplo, com a existência de um marco regulatório com ambigüidade mínima em relação a quem se aplicam as normas ou a quais são os critérios a serem utilizados em cada situação. Quanto menor a incerteza a respeito dos direitos e obrigações de cada uma das partes, menor será a margem de negociação entre elas, a qual tende a minimizar o impacto das assimetrias de poder e, desta maneira, incrementar a efetividade da regulação. Porém, veremos que a possibilidade de se estabelecer tais condições está limitada por diversos obstáculos.

Falar de regras de jogo supõe considerar um leque de variáveis muito abrangente e heterogêneo, tais como fundamentações ideológicas dos agentes que participam na relação, vigência de normas formais e informais, recursos de poder de cada uma das partes, espaços e margens da ação política, natureza moderada ou maximalista das demandas ou oportunidades de formação de coalizões. Nesse plano dirimem-se questões relativas à preservação do caráter público dos serviços privatizados, os efeitos redistribuídos da gestão privada de serviços, a definição dos receptores dos serviços em termos de usuários ou clientes, os limites à aplicação de critérios exclusivamente empresariais na prestação dos serviços etc.

Uma primeira definição relativa ao sentido da regulação, não necessariamente explícita nem unívoca, requer decidir se o Estado orientará sua ação a resguardar o interesse geral, implicando com isso uma clara atitude de proteção e defesa dos direitos dos usuários, ou se se limitará 
a atuar como árbitro entre agentes privados, notoriamente desiguais, reunidos em um mesmo mercado ainda que defendendo interesses essencialmente contraditórios. Entre esses extremos (que poderiam ser considerados como tipos ideais antagônicos) existe uma variada gama de fórmulas possíveis, que se desdobram em cenários nos quais variam as relações de força entre os agentes envolvidos e, em consequiência, demandam diferentes capacidades institucionais por parte do estado regulador.

Em princípio, não deveriam existir dissonâncias importantes entre a magnitude das responsabilidades regulatórias e as capacidades institucionais disponíveis para exercê-las. Frente a essa necessidade de adequação, existem duas opções possíveis. Ao se considerar que não se pode renunciar à responsabilidade regulatória e esta é irredutível, tais capacidades deveriam elevar-se até o nível compatível com o das competências assumidas nesse sentido. Dito de outra forma, deveriam limitar-se os objetivos regulatórios em função do reconhecimento de debilidade das capacidades institucionais disponíveis ${ }^{11}$.

$\mathrm{Na}$ Argentina, as regras de jogo foram-se configurando durante o próprio processo de privatização das empresas estatais. O caráter excepcional da crítica situação econômica e política em que se estabeleceram as bases das relações entre Estado, empresas e usuários, deixou sua marca sobre as modalidades que iriam se consolidando na prestação e regulação dos serviços. A urgência governamental em transferi-los ao setor privado aumentou significativamente a capacidade de negociação empresarial.

Por outo lado, a ausência de debate e a própria urgência limitaram as possibilidades de organização e incidência dos usuários nas definições iniciais, contradizendo nos fatos as supostas expectativas do discurso oficial. Efetivamente, em 1990, quando ainda não se havia concretizado nenhuma transferência ao setor privado, o então Ministro de Obras Públicas assinalava que:

“o Governo está deixando a administração das empresas de serviços nas mãos da sociedade, e a sociedade as controlará, exigindo-lhes eficiência, bom serviço (....). O cidadão levantará a bandeira do interesse público ${ }^{12}$."

Suas palavras expressavam a pouca prioridade dada à questão da regulação, durante a etapa inicial das privatizações.

Uma das primeiras regras de jogo que, de fato, mais contribuiu para limitar a capacidade regulatória do Estado foi a defasagem temporal entre o momento de privatização dos serviços, o de sanção dos marcos regulatórios e o de criação dos órgãos regulatórios dos serviços transferidos ao setor privado. $\mathrm{Na}$ ausência de marcos regulatórios, os contratos de concessão fixaram condições que logo condicionaram ou entraram em contradição com os marcos posteriormente aprovados. 
Entretanto, as situações mudaram segundo a época e o tipo de serviço considerado. O serviço telefônico, o transporte aéreo e o ferroviário foram privatizados sem prévia sanção do respectivo marco regulador, nem criação do ente regulador correspondente. Os serviços elétricos e de gás foram privatizados com o marco regulador sancionado, mas sem um ente regulador estabelecido. Nos casos do fornecimento de água potável e do serviço de correio, a sanção do marco regulador e a constituição do ente regulador foram prévios à transferência ao concessionário. Existem, por outro lado, casos extremos como o setor aéreo no qual esquemas reguladores específicos nem sequer chegaram a ser definidos.

O problema central, que permitiria explicar a criação tardia dos organismos de regulação, tem sido a ausência de critérios preestabelecidos acerca do funcionamento esperado dos serviços e dos próprios organismos de controle. Essa circunstância colocou em evidência, mais uma vez, a vigência de um estilo decisório no qual a motivação (compulsão a agir) prevaleceu sobre a compreensão do problema, sobre o entendimento de em que campo se estava atuando (Hirschman, 1964). A literatura assinala que a incerteza a respeito dos alcances do marco regulador pode gerar formas de seleção adversas, ao atrair investidores dispostos a assumir riscos mais altos, ou aqueles com maior capacidade para exercer influência e captar rendas em detrimento dos consumidores (Bitrán e Saavedra, 1993). Na prática, a indefinição normativa promoveu comportamentos oportunistas por parte de algumas empresas que, como no caso do transporte ferroviário, ganharam as licitações com ofertas de investimentos e de pagamento de títulos ao Estado que nunca chegariam a cumprir e que em poucos anos seriam renegociados.

Um dos problemas decorrentes da falta de marcos regulatórios prévios é a possibilidade de que as empresas reclamem a validade do estipulado nos contratos frente às obrigações mais graves ou controles mais estritos que poderiam surgir de posteriores tentativas de regulamentar aspectos dos serviços. $\mathrm{O}$ caso da elaboração do marco regulatório telefônico, que foi encomendada à Secretaria de Telecomunicações sobre a base dos princípios, de acordo com os prazos fixados nas condições de licitação (Hill e Abdala, 1993), implica, de fato, no reconhecimento formal desta limitação.

Porém, as conseqüências mais visíveis desse tipo de defasagem se manifestariam mais tarde em casos, tais como o controvertido rebalanceamento das tarifas telefônicas contemplado nos contratos de venda da ex-ENTEL (Empresa Nacional de Telecomunicações); a autorização à empresa Águas Argentinas para instalar medidores nos imóveis de propriedade horizontal e faturar em bloco aos consórcios, que deveriam se encarregar de dividir os custos entre os vizinhos; ou a 
possibilidade outorgada a essa mesma empresa para cobrar uma taxa por infra-estrutura, o que lhe permitiria recuperar, mediante a cobrança a cada novo cliente, o investimento necessário para estender a rede.

$\mathrm{Na}$ maioria dos casos, o debate parlamentar esteve ausente nas definições iniciais acerca do controle dos serviços. Isso eliminou uma voz decisiva nessa inicial e crucial etapa e, com o tempo, condicionou severamente os atuais esforços do Congresso por impulsionar um maior protagonismo parlamentar em seu papel regulador dos entes regulatórios. Por iniciativa do Poder Executivo, formalizada por meio de decretos, constituíram-se o Ente Tripartido de Obras e Serviços Sanitários (ETOSS), a Comissão Nacional de Telecomunicações (CNT) e a Comissão Nacional de Correios e Telégrafos (CNCT), logo unificadas na Comissão Nacional de Comunicações (CNC); e a Comissão Nacional de Transporte Ferroviário (CNTF), fundida posteriormente com o organismo de controle de transporte automotor em uma única Comissão Nacional de Regulação do Transporte (CNRT). Os únicos entes criados por lei foram o Ente Nacional Regulador do Gás (ENARGAS) e o Ente Nacional Regulador da Eletricidade (ENRE).

Do ponto de vista jurídico, a criação mediante uma lei ou um decreto supõe uma condição diferente para os organismos criados desta forma. No primeiro caso, o funcionamento dos entes sustenta-se na maior legitimidade e permanência do instrumento legal, enquanto nos casos de entes criados por decreto, sua ação fica sujeita a uma vontade executiva muito mais facilmente alterável (Thury Cornejo, 1995). Talvez essas diferenças expliquem as sucessivas modificações sofridas pelos organismos de controle do transporte ferroviário e de comunicações, em comparação com a maior estabilidade evidenciada pelos organismos de regulação do fornecimento de eletricidade e gás.

Como assinalado acima, outra questão-chave na configuração de regras de jogo entre reguladores e prestadores é a dificuldade para estabelecer critérios transparentes e inequívocos, aplicáveis aos diversos aspectos que compõem sua relação. Ainda que os marcos reguladores tenham se incorporado, geralmente, às recomendações derivadas da experiência internacional em matérias, tais como razoabilidade das tarifas, defesa dos direitos dos usuários, competência ou eficiência, essas definições são quase sempre muito abstratas, e sua aplicação depende da possibilidade de desagregá-las até o nível requerido pelas exigências da gestão. A dificuldade agrava-se pela inexistência de padrões precisos ou benchmarks que indiquem níveis aceitáveis para os diversos aspectos que envolvam a prestação dos serviços ${ }^{13}$.

Um nível de análise mais concreto, que também afeta o conteúdo das regras de jogo, é a escolha dos critérios técnicos para o exercício da regulação, o reconhecimento da especificidade e das vantagens e 
problemas inerentes a cada um deles. O price cap que, com diversas variantes, é o critério inspirador da fixação de tarifas, estabelece preços que durante determinado período não podem crescer acima da taxa RPI (Índice de Preços ao Consumidor - X) onde $\mathrm{X}$ representa uma estimativa ex ante dos aumentos de eficiência da empresa e fixa-se externamente. Ao final desse período, o valor de $\mathrm{X}$ redefine-se e os aumentos de eficiência superiores a essa taxa são mantidos como benefício da empresa. Embora esse esquema ofereça incentivos para reduzir a estrutura de custos, o ajuste de $\mathrm{X}$ apresenta problemas quando não é definido explicitamente o mecanismo de modificação, gerando a possibilidade de comportamentos oportunistas, tanto da empresa quanto do regulador. Na prática, introduzse uma importante parcela de discricionariedade, gerando contínuos processos de negociação entre o regulador e o regulado, o qual poderia promover uma tendência a reduzir custos, deteriorando a qualidade dos serviços e limitando os investimentos.

Em síntese, dentro do amplo leque de aspectos que conformam as regras de jogo examinadas, dois eixos fundamentais podem ser assinalados. O primeiro vincula-se com os debates e a articulação dos consensos necessários em torno da importância e dos efeitos diferenciais da regulação sobre a atividade econômica e a vida cotidiana, o qual remete a um nível de análise estritamente político. Até o presente momento, as demandas de diversos agentes preocupados com o tema não parecem ter tido o peso suficiente como para incorporar o tema à agenda de questões prioritárias, nem para gerar uma resposta estatal consistente em uma tarefa sistemática de fortalecimento e adequação dos esquemas institucionais inicialmente criados.

O segundo eixo abrange um conjunto de aspectos técnico-normativos que merecem a atenção dos especialistas e procuram alcançar maior precisão, ou evitar contradições e falhas na definição dos direitos e obrigações de cada um dos agentes, assim como dos procedimentos a seguir frente a circunstâncias diversas. Nem mesmo neste nível, como se depreende da análise efetuada, parecem existir condições propícias para que os entes possam dispor de critérios e mecanismos de ação firmemente estabelecidos.

\section{Relações interinstitucionais}

Uma segunda fonte de déficit de capacidade institucional pode originar-se na dinâmica gerada a partir das relações estabelecidas entre os diferentes agentes envolvidos no processo de regulação/prestação/uso dos serviços. Embora, até agora, não se fizeram maiores diferenciações com respeito à identidade dos agentes, por razões de simplificação da 
análise, cabe assinalar que em cada um dos vértices do triângulo apresentado na Figura 1 intervém mais de um agente.

Por exemplo, ainda que tenhamos nos referido até agora aos entes regulatórios, são diversas as instituições públicas, estatais ou não, cuja atuação esperada deveria auxiliar os fins regulatórios, ainda que, em alguns casos os limitem, bloqueiem ou os redirecionem em diversos sentidos. Basta mencionar os órgãos do Poder Executivo que exercem tutela sobre entes regulatórios; as comissões permanentes ou ad hoc criadas por ambas as câmaras do Poder Legislativo para intervir em diversos aspectos da regulação; os órgãos estatais e privados de defesa do consumidor ou a Defensoria do Povo. Ainda que nossa análise concentre-se nos entes, não se pode desconhecer o decisivo papel que podem desempenhar essas outras instituições quando essas buscam dirimir as questões suscitadas pela relação regulação/prestação.

Tanto a teoria quanto a experiência internacional coincidem quanto à necessidade de que as agências regulatórias tenham autonomia. Esse critério baseia-se na necessidade de dar continuidade ao trabalho das equipes técnicas e das autoridades político-administrativas, para além da duração de um governo. Também pretende isolá-las de pressões políticas e assim lhes oferecer maiores possibilidades de que sua ação se guie fundamentalmente por critérios técnicos. Dessa forma, seria assegurada a necessária previsibilidade para tomar decisões que, geralmente, condicionam por muitos anos a oferta do serviço.

Ainda que, na Argentina, os entes se organizem sob a forma de organismos autárquicos, em alguns casos, a falta de autonomia em relação ao poder político tem sido manifestada e é objeto de numerosas críticas. Naturalmente, a situação varia segundo os organismos, mas a intervenção do Poder Executivo nas decisões dos entes é recorrente. Existe um certo consenso em assinalar que o ETOSS e a ex-CNT parecem haver sido os mais influenciados pelo Executivo ${ }^{14}$.

A independência em relação ao poder político é considerada uma forma de garantia da segurança jurídica e da proteção das empresas prestadoras contra medidas arbitrárias. Porém, prescrições desse tipo merecem ser relativizadas. Não é possível supor que visando garantir o futuro dos investimentos das empresas, deva-se vetar a possibilidade ou a necessidade de revisar certos critérios de controle ou de fixar limites para determinadas atividades, particularmente, nos casos em que a transformação tecnológica poderia produzir a obsolescência das normas que regem a relação. Mais do que a rigidez dos critérios inicialmente fixados, a segurança jurídica poderia ser protegida pela existência de mecanismos claros de discussão e redefinição de critérios regulatórios que tomem por base um conjunto de indicadores já aceito. 
Até agora, a experiência argentina parece indicar que a falta de independência em relação ao poder político e o questionamento das normas vigentes tornam-se mais prejudiciais para os usuários que para as empresas reguladas. Cabe citar, nesse sentido, que as renegociações dos contratos de prestação dos serviços ferroviários, de água potável e esgoto surgiram por iniciativa das próprias empresas.

Um esclarecimento pertinente nesse ponto é o reconhecimento de que os critérios técnicos que produziriam um maior grau de previsibilidade, respondem fundamentalmente a noções de regulação econômica, isto é, a esquemas que, na ausência de concorrência, colocam limites os mais semelhantes possíveis aos estabelecidos pelo mercado. De fato, circunscrever-se a estes tipos de critérios técnicos transforma os entes em avalistas das regras de mercado, o que deixa sem cobertura um conjunto de situações ${ }^{15}$.

Às vezes, também aceita-se ampliar a definição do papel dos entes, adicionando-lhes tarefas próprias da defesa dos interesses dos usuários; ou criam-se e reforçam-se instâncias de relação com esses que contemplem mecanismos claros de atenção, de prioridades, de necessidades, de processamento e resposta às demandas, de consulta e participação etc. Nesse sentido tem sido apresentada a opção de criar dois organismos diferentes para exercer essas funções: um organismo regulador centrado na relação produção/regulação e uma defensoria que atue na interface regulação/consumo, com capacidade para processar eficazmente as demandas dos usuários, os agentes mais frágeis desta relação, e com faculdades para requerer informação e exigir respostas do organismo de regulação como das empresas.

Por outro lado, para uma maior clareza das funções que desenvolvem os organismos de regulação, também é desejável uma distribuição de funções mais precisa entre as áreas a cargo dos entes e as desempenhadas por instituições da Administração Central (i.e. Secretarias de Energia, de Transporte, de Comunicações, de Recursos Naturais e Meio Ambiente), que possuem claras sobreposições em temas que também são matéria dos entes.

A criação da CNRT, que significou separar as tarefas de fiscalização do transporte de um conjunto de tarefas de planejamento, gestão e promoção do sistema de transporte atribuídas à sua antecessora, a Comissão Nacional de Transporte Ferroviário (CNTF), poderia ter se constituído em um avanço na direção indicada. Em sentido contrário e associado à falta de autonomia, a ação da CNC se confunde com a da Secretaria de Comunicações. Considerando que aquela tinha faculdades para decidir sobre a reestruturação tarifária, foi a Secretaria que teve a incumbência da exposição de motivos e os trâmites para sua concretização. 
Ainda que, como já assinalamos, a autonomia seja um requisito geralmente aceito, no caso de agências que tomam decisões quase judiciais (quando fixam preços, especificações técnicas ou garantem o devido processo anteconflitos), tal autonomia não deveria equivaler a uma total ausência de apoio político, que terminaria por fazer com que esses organismos se tornassem mais vulneráveis às pressões dos regulados.

Uma das garantias contra o risco de captura ${ }^{16}$ dos reguladores por parte das empresas reguladas é precisamente o fortalecimento dos organismos, tendo por base sinais políticos claros que mostrem a importância da função regulatória na agenda estatal e os benefícios que derivam de sua otimização. Uma maior visibilidade da gestão dos entes e o reforço de seus mecanismos de prestação de contas permitiriam alcançar um ponto de equilíbrio entre a necessária autonomia, a legitimidade e a proteção quanto à captura por parte das empresas reguladas.

Atualmente, a Auditoria Geral da Nação está encarregada do controle externo dos entes, no entanto, o controle interno está a cargo do Sindicato Geral da Nação. Um caminho a explorar a fim de fortalecer a accountability dos entes, poderia ser o controle por parte de comissões ad hoc do Parlamento. Existem diversos projetos legislativos que propõem esquemas desse tipo, associados, em alguns casos, a reestruturações globais do marco institucional e da lógica de funcionamento dos organismos regulatórios ${ }^{17}$.

Aspiazu e Vispo (1994) sugerem que a criação de um "superente" centralizado impediria a superespecialização dos funcionários e, em consequiência, contribuiria com a redução das probabilidades de associação por parte das empresas reguladas. Outra opção é o fortalecimento do papel que desempenha a Auditoria Geral da Nação, tanto no controle dos entes como das empresas prestadoras.

Outro problema a assinalar nesse nível de análise é a falta de relação e de desenho conjunto de políticas entre entes que se ocupam de áreas vinculadas, como é o caso do ENRE e o ENARGAS no setor energético. Por outro lado, apesar de que a unificação dos organismos de controle de transporte na CNRT prometia ser um meio para aumentar a coerência na aplicação de políticas nesta área, os resultados não parecem confirmar essa expectativa ${ }^{18}$.

Cabe também considerar diversos aspectos relativos às relações interinstitucionais que afetam especificamente a relação entre regulação e consumo. Por exemplo, a dispersão institucional torna mais complexo o vínculo dos usuários com os reguladores, ao ter que lidar com uma multiplicidade de organismos e de critérios normativos diferentes de acordo com o serviço de que se trate. É inegável que os serviços têm particularidades que os tornam dificilmente equiparáveis do ponto de vista técnico, 
mas no caso das redes de serviços domiciliares (água corrente e esgoto, eletricidade, gás natural e telefonia básica), existe um conjunto de aspectos comerciais e de atenção aos usuários que poderiam unificar-se sem maiores impedimentos técnicos (i.e. interesses punitivos, prazos de corte de serviço por atraso de pagamento, prazos para a reparação de falhas). Sua dispersão parece obedecer especialmente à falta de acordos encaminhados a atingir um maior grau de coerência na aplicação das políticas regulatórias.

A inclusão das associações de usuários nos organismos de controle dos serviços encontra-se ainda pendente. Prevista na Constituição Nacional, essa modalidade de participação poderia moderar os riscos de captura do regulador por parte das empresas reguladas e a notória assimetria de recursos técnicos, econômicos e de informação existente entre empresas e usuários. Até o momento, apenas no caso do ETOSS criou-se um âmbito participativo deste tipo, ainda que seu funcionamento tenha sido muito limitado ${ }^{19}$.

Em outro âmbito, é significativo que os entes só atendam em segunda instância as reclamações dos usuários e, em geral, se recusem a tornar-se receptadores dessas queixas, ao mesmo tempo que se limitam as possibilidades de ingerência de outros organismos, tais como a Direção Nacional do Consumidor ou do Defensor do Povo. A Lei 24.240 de Defesa do Consumidor, sancionada em 1993 em uma tentativa de evitar situações de falta de proteção dos usuários, adicionou um capítulo dedicado à prestação de serviços públicos, que fixa pautas a seguir frente a um conjunto de situações que costumam ser conflitantes ${ }^{20}$. Uma vez que a aplicação dessa lei ficou reservada a situações não contempladas na legislação específica, as empresas tendem a rechaçar os critérios que essa norma estabelece, quando lhes parecem menos favoráveis que os estipulados pelos marcos regulatórios.

Uma situação semelhante se produz no que diz respeito à proteção contra condutas monopolistas. Embora, em geral, os serviços públicos de gestão privada apresentam condições de monopólio natural e em outros casos se mantiveram importantes reservas de mercado pelos esquemas contratuais (Gerchunoff, 1995), a própria direção de defesa da concorrência, autoridade de aplicação da norma que defende o interesse dos consumidores, não considera que a Lei de Defesa da Concorrência seja aplicável aos serviços públicos, ainda que esses constituam o exemplo por excelência de atividades com características de monopólio natural. É sugestivo, a esse respeito, que esse organismo tenha como objetivo quase exclusivo garantir o correto funcionamento dos mercados e evitar atos que lesionem a concorrência ou constituam abuso de poder dominante no mercado. 
Para fins de atendimento das demandas dos usuários, sua unificação em uma única instância contribuiria para facilitar os trâmites. Uma medida desse tipo não necessariamente implica em fundir os organismos em um "superente" do tipo mencionado acima. Bastaria criar áreas comuns de atenção aos usuários, o que por sua vez favoreceria um funcionamento descentralizado e mais acessível a esse tipo de agências. As vantagens desse esquema devem ser avaliadas, porém, à luz da maior complexidade que introduz na tramitação das demandas, e do cuidado que requer o desenho dos respectivos mecanismos, para evitar que se tornem emaranhados burocráticos que aproximam os balcões de reclamação dos bairros, mas se afastam das respostas.

Uma conclusão parcial sobre este ponto leva-nos novamente ao nível de análise prévio: a resposta à pergunta sobre o que se pretende que seja a regulação é pré-requisito da clareza na divisão de funções e da relação entre os organismos encarregados. Também nos permite colocar em destaque além dos entes regulatórios, uma definição abrangente de regulação que amplia o alcance da rede institucional responsável pelo seu exercício.

\section{Organização interna e atribuição de funções}

Assinalar que os modelos e estruturas organizacionais de uma instituição devem adequar-se à natureza da missão, objetivos e metas que persegue, poderia parecer uma verdade óbvia. No entanto, são poucas as que conseguem plenamente esse ajuste entre meios e fins. Em parte porque seus objetivos ou o alcance dos mesmos não são claros e, por isso, torna-se difícil estabelecer relações de causa-efeito entre um certo esquema organizacional e sua aptidão para alcançar seus objetivos. E, em parte, também, por falhas de desenho, vazios ou superposições de funções e deslocamento de objetivos devidos a interferências políticas ou lutas de poder.

Observados por este ângulo, os entes regulatórios contariam com importantes vantagens constitutivas. Por sua natureza, trata-se em geral de organizações que podem desenhar-se ex novo, contam com uma missão legítima e um amplo consenso social, não recebem o legado de pesadas burocracias nem culturas patológicas e, potencialmente, estão em condições de estabelecer funções de produção mais racionais e eficazes.

Porém, a experiência argentina demonstra que essas organizações não são imunes aos problemas descritos acima: sua missão não tem um alcance definido; suas funções não são devidamente atribuídas às unidades e funcionários responsáveis; e sua subordinação ao poder político as 
expõe a verdadeiros esvaziamentos no plano decisório. Vejamos alguns aspectos mais desagregados dessa problemática.

Todos os entes regulatórios criados até hoje consideram, em sua organização, a constituição de unidades gerenciais especializadas segundo as funções que deverão desenvolver. A CNRT é uma exceção a essa regra, pois essas unidades coexistem matricialmente com um conjunto de gerências responsáveis de supervisionar os distintos modos de transporte. Este esquema poderia tornar-se funcional se os objetivos e ações das gerências estivessem bem delimitados, o que não ocorre. Para ilustrar esse ponto, os registros de operadores do transporte automotor se encontram a cargo da Gerência de Controle Técnico e não da Gerência de Controle de Permissões de Transporte Automotor, que só coordena e controla os aspectos administrativos do registro. Tampouco existe clara delimitação das ações correspondentes às Gerências de Controle e de Segurança. Além do mais, essa última só exerce controle sobre o transporte ferroviário e não sobre o automotor. E assim, poderiam citar-se numerosos outros exemplos.

Em matéria de desconcentração, o único organismo em que se realizaram avanços nesse sentido é o ENARGAS. No decreto de criação deste ente previu-se a existência de representações localizadas em cada área de distribuição de gás, nas quais se dividiu o território nacional no momento da privatização, com o propósito de atender em cada jurisdição a relação entre as empresas distribuidoras e os usuário ${ }^{21}$. Esse critério levou-se à prática mediante a criação de cinco representações regionais que dependem da Gerência de Regiões e que estão encarregadas da representação do organismo, do atendimento das reclamações e da coleta e destino de questões formuladas pelas províncias e municípios.

Em outro sentido, a sede da CNRT está na cidade de Buenos Aires e ainda que seu decreto de criação a habilite a estabelecer representações nas províncias, a decisão correspondente a essa habilitação ainda não foi efetivada. Também o ENRE funciona centralizadamente na Capital Federal. No caso do ETOSS, a área regulada não abrange todo o território nacional, mas apenas a Capital Federal e treze prefeituras da província de Buenos Aires que são atendidas por uma sede localizada na região do centro da cidade. A particularidade desse organismo é a participação conjunta, na sua diretoria, de representantes da cidade de Buenos Aires e da província de Buenos Aires. No início, estava prevista a assinatura de convênios com os municípios compreendidos pela concessão, a fim de descentralizar o atendimento em agências que funcionariam no âmbito dos conselhos de vizinhança ou nas sedes municipais da área regulada, facilitando assim o encaminhamento de consultas e reclamações por parte dos usuários dessas zonas. Até hoje, no entanto, esses convênios não se concretizaram. 
O debate sobre a centralização/descentralização da administração não produziu resultados conclusivos acerca da conveniência de uma ou outra modalidade de funcionamento. No caso dos organismos que estamos focalizando nesse trabalho, a existência de sedes em pontos mais afastados do território facilitaria o acesso dos usuários, mas também aumentaria a necessidade de coordenação e de recursos para seu funcionamento. Em qualquer caso, uma medida desse tipo apenas resolve uma parte do problema. Também deve se prever que não fique diluído o âmbito geográfico de aplicação do controle do funcionamento dos serviços, e de sua qualidade, ao afastar-se esse controle da Capital Federal.

A direção de todos os organismos regulatórios está a cargo de corpos colegiados designados pelo Poder Executivo. Apenas nos casos do ENRE e do ENARGAS há a participação do Congresso na nomeação e remoção dos diretores, ainda que essa intervenção tenha caráter não vinculatório. No restante dos entes, a legislação estabelece que a remoção dos diretores deve estar fundamentada. A margem de discricionariedade do Poder Executivo que isso supõe e a falta de especificação das modalidades de intervenção do Parlamento ou de outros organismos de controle, diminui a possibilidade de independência desses funcionários com respeito a decisões e orientações governamentais.

Em geral, aos diretores se aplicam as normas sobre incompatibilidades fixadas para os servidores públicos, mas apenas para alguns deles se estabelecem prazos posteriores a sua desvinculação, nos quais é proibido ter interesses nas empresas reguladas. Em uma tentativa de prevenir o possível risco de captura, o decreto de criação da CNRT proíbe que os diretores tenham interesses relacionados com empresas de transporte até dois anos após terem cessado seus mandatos. No caso da CNC, o prazo se reduz para um ano. No entanto, a legislação não especifica os mecanismos a serem empregados para comprovar o respeito dessa norma. Inclusive, não existem impedimentos em matéria de incompatibilidade para os diretores do ETOSS, do ENARGAS ou do ENRE.

Ao entrarmos nos níveis mais desagregados da estrutura organizacional dos entes, percebem-se outras deficiências. Primeiramente, para que os órgãos de regulação possam ser avalistas efetivos da proteção do interesse público, envolvido na prestação dos serviços, as funções que lhes atribuem devem poder ser desagregadas em ações atribuíveis às unidades organizacionais que as compõem. Sem esse nível de especificação, é impossível que o enunciado genérico de objetivos se faça efetivo na gestão dos entes. Não obstante, a CNRT não tem definidas suas competências e funções a partir do segundo nível de abertura de sua estrutura organizacional. Ainda que necessária, essa definição de competências é, no entanto, insuficiente para garantir seu exercício efetivo, alterado 
freqüentemente por interferências políticas na cadeia de comando, que mudam e desvirtuam a linha de autoridade ${ }^{22}$.

Para citar outro exemplo, o decreto de criação da CNRT estabelece os deveres de "garantir a publicidade de suas decisões, incluindo os antecedentes com base nos quais elas foram tomadas" (art. 5.a); ou "receber e tramitar com diligência toda queixa, denúncia ou solicitação de informação dos usuários ou de terceiros interessados relativos à adequada prestação dos serviços". A Gerência de Qualidade e Prestação de Serviços está incumbida dessas funções, assim como da proteção dos direitos dos usuários e da comunicação com a comunidade. Em função dessa responsabilidade, deve desenvolver, entre suas ações, a coordenação dos dispositivos de coleta de informação para monitorar o nível de satisfação dos usuários.

Ainda que isto represente um avanço em comparação aos serviços de eletricidade, gás e água potável, em que não se tem formalizada a obrigação de sistematizar esses mecanismos de coordenação, requer-se uma maior especificação das formas de cruzar a informação proveniente deste tipo de fonte com a proveniente das fiscalizações que realiza a Gerência de Controle Técnico, de modo a obter um panorama da obediência aos contratos, da qualidade dos serviços e da manutenção da infra-estrutura e dos bens.

Outras ações relacionadas com essa responsabilidade, tais como a definição dos regulamentos de proteção ao usuário e o estabelecimento de programas de educação e difusão dos direitos dos usuários de transporte, estão pendentes de execução, apesar de estarem previstas entre as missões e funções do organismo. Tampouco existem maiores precisões formais acerca das atribuições das diversas unidades organizacionais para o reconhecimento de situações irregulares que poderiam ser sancionadas, da determinação das sanções proporcionais às faltas cometidas e da possibilidade de conseguir que as empresas as acatem, o que até o momento não tem ocorrido.

Embora que entre os deveres da CNRT conste a solicitação de informação e documentação das empresas de transporte para verificar e avaliar o desempenho do sistema de transporte e a devida observância da fiscalização encomendada, isso não se reitera na atribuição de responsabilidades às gerências que têm incumbência no tema (Gerência de Concessões Ferroviárias, Gerência de Qualidade e Prestação de Serviço, Gerência de Controle Técnico e Gerência de Segurança no Transporte).

Em síntese, existem ainda fortes brechas entre as responsabilidades atribuídas aos entes, sua distribuição em termos operacionais entre as diferentes unidades organizacionais que os integram e o exercício efetivo de suas competências por parte dessas unidades. Junto com os déficits 
em matéria de descentralização funcional e os problemas de incompatibi-

lidades não resolvidos, os fatores assinalados contribuem para reduzir a capacidade institucional dos entes para cumprir sua missão.

\section{Disponibilidade de recursos físicos e humanos}

A origem dos recursos e os mecanismos estabelecidos para sua obtenção e atribuição constituem indicadores eloqüientes acerca do grau de independência dos entes regulatórios com relação às empresas e ao poder político. Neste aspecto, a situação dos entes é heterogênea. O ENARGAS, o ENRE e a CNC confeccionam seus orçamentos e os apresentam ao PEN (Poder Executivo Nacional) para sua inclusão no projeto de orçamento nacional. No ENARGAS e no ENRE os recursos para o financiamento provêm fundamentalmente das taxas de inspeção e controle que pagam diversos agentes do sistema, assim como das multas aplicadas. Em ambos os casos, estipula-se que os projetos de orçamento devem ser publicados para que possam ser analisados e, eventualmente, cumpridos pelas partes envolvidas. O ETOSS estabelece seu próprio orçamento e os recursos provêm fundamentalmente de uma porcentagem $(2,67 \%)$ do faturamento aos usuários ${ }^{23}$. Por último, diferente dos demais organismos, que elaboram seu próprio orçamento, o da CNRT é confeccionado pela Secretaria Nacional de Orçamento do Ministério de Economia e Obras e Serviços Públicos.

$\mathrm{O}$ financiamento, baseado em uma taxa percentual sobre a renda das empresas reguladas permite, teoricamente, que os entes não sofram as restrições que enfrenta o conjunto da administração e, ao mesmo tempo, resguarda sua autonomia em relação ao poder político, mas se cria, por outro lado, um problema de incentivos, já que os incrementos tarifários, e o correspondente aumento do faturamento aumentam os recursos. Dificilmente os organismos levariam a cabo medidas que têm como efeito "não-desejado" a redução de seu orçamento. Além disso, as possíveis vantagens desse tipo de mecanismos foram diluídas pela prática das autoridades econômicas no sentido de dispor, a seu arbítrio, dos fundos que os entes recebem ${ }^{24}$.

Como conseqüência direta desse manejo dos recursos, os organismos vêm paulatinamente reduzindo seus recursos nos sucessivos exercícios orçamentários. O ENARGAS teve, em 1993, um orçamento de $\$ 9.200 .000$, cifra estimada antes do funcionamento do ente. Posteriormente, reajustou seu montante a $\$ 12.457 .155$. Para o ano 1994 , foi fixado um orçamento de $\$ 26.550 .000$ que foi aprovado pelo Congresso da Nação 
mediante a Lei de Orçamento, mas a execução orçamentária alcançou \$ 25.842.021. Para o ano 1995, a previsão havia se reduzido a \$22.449.199. No caso do ENRE, seu orçamento para 1994 estava em volta dos 25 milhões de dólares ${ }^{25}$. Em 1995, a estimativa caiu para \$15.558.088, mas, conforme a redução disposta pelo Ministério da Economia, o orçamento efetivamente executado foi de apenas \$13.200.000. Por sua parte, a CNTF teve a sua disposição, em 1995, um orçamento de 7,9 milhões de dólares que posteriormente foram reduzidos a 6,3 milhões em $1996^{26}$. Os recursos aumentaram em 1997 para 13,3 milhões, depois da fusão dos diversos organismos de controle de transporte na CNRT. O orçamento da CNT, ao contrário, tem sido mais alto que o dos demais entes e demonstra uma evolução crescente que a maior parte dos organismos não apresenta. De 42,8 milhões de dólares em 1994, passou para 54,3 milhões em 1995 e para 63 milhões em 1996.

Os orçamentos constituem, de toda forma, um simples reflexo monetário da disponibilidade, ou não, dos recursos necessários para que os entes possam cumprir cabalmente com sua missão. Existe evidência de que muitos deles não contam com os meios materiais e os recursos humanos que se requerem para desenvolver as diferentes tarefas especializadas de sua incumbência. A função de produção implícita na integração dos insumos empregados — infra-estrutura, despesas com pessoal e bens ou serviços não pessoais — não parece, freqüentemente, ter correspondência com a exigida pela natureza da tarefa técnica que deve desempenhar.

Devido aos sucessivos cortes orçamentários, muitas áreas-chave ficaram sem responsável ou com pessoal insuficiente para controlar as empresas prestadoras. Após a unificação dos órgãos de controle do transporte automotor e ferroviário em uma única CNRT, a dotação de pessoal se reduziu à metade e os contratos se limitaram a um prazo máximo de seis meses. Também se diminuiu os salários do pessoal e não se renovaram numerosos contratos em áreas críticas ${ }^{27}$.

Outro dos insumos-chave para o exercício do controle e um dos pontos críticos da relação regulador/regulado é a informação sobre o desempenho empresarial, à qual nos referimos no ponto anterior. Em todos os casos, a norma regulatória prevê a obrigação dos prestadores de prover a informação solicitada pelos entes. Complementariamente, os entes realizam inspeções e auditorias nas empresas ou contam com serviços de terceiros para realizá-las. Em alguns casos realizaram-se pesquisas para conhecer a opinião dos usuários com relação aos serviços, ainda que esse mecanismo não seja uma prática regular dos entes. Por exemplo, a modalidade de controle de qualidade da água potável realizada pelo ETOSS, inclui controles realizados pela própria empresa (que são auditados), 
controles realizados pelo ente e contratos com terceiros que levam a cabo as análises correspondentes em seus laboratórios. Pelo menos formalmente, o nível de confiabilidade destes procedimentos fica garantido pela possibilidade do ente de acessar os arquivos de reclamações informatizados que a empresa possui.

Apesar da atribuição formal que os entes têm para obter das empresas informação com fins de controle, estas nem sempre cumprem exaustivamente com essa obrigação. Ademais, em certos casos, as assimetrias existentes lhes permitem manipular dados relevantes acerca de seus comportamentos e custos sem que o regulador consiga detectar a manobra, facilmente. Um relatório da Auditoria Geral da Nação ${ }^{28}$, referindo-se aos controles que exerce a CNTF em relação à segurança e os acidentes no transporte ferroviário de carga, destaca a ausência de programas de análise e avaliação da segurança do transporte ferroviário que estabeleçam metas quantificáveis, assim como a falta de acompanhamento dos planos e ações nesse sentido ${ }^{29}$. A implementação de sistemas informatizados que permitam o funcionamento em rede com as empresas, tal como disposto pela CNC, permitiria resolver alguns obstáculos deste tipo ${ }^{30}$.

Em síntese, os recursos orçamentários dos entes, salvo exceções, demonstram uma clara tendência à queda. Isso reduz suas dotações de recursos humanos e coloca em situação precária as condições de trabalho de seu pessoal. As interferências políticas contribuem, ademais, para o deslocamento de postos críticos de funcionários que cumprem um papelchave nos esquemas de controle. Por último, as reticências empresariais, unidas a uma certa falta de sistematização nos controles, dificultam a obtenção dos dados técnicos que constituem um insumo indispensável da função reguladora.

\section{Políticas de pessoal e capacidades individuais}

Todos os organismos de regulação se caracterizam por ter folhas de pessoal reduzidas e integradas por uma alta porcentagem de profissionais, na sua maioria engenheiros, advogados e contadores públicos. Como exemplo, podem citar-se os casos da dotação do ENARGAS, que por volta de 1995, contava com 134 agentes. Profissionais e técnicos constituíam $81 \%$ de seus recursos humanos, e os $19 \%$ restantes era pessoal administrativo. O ETOSS, por sua vez, tinha uma dotação de 72 postos, dos quais estavam preenchidos 54. Deste total, 73\% possuíam níveis universitários, distribuídos entre 19 engenheiros, 7 advogados, 
4 contadores públicos, 4 arquitetos e 3 economistas. $\mathrm{O}$ restante da folha

de pessoal correspondia a outras profissões ou não era de nível universitário.

Desde então, a orientação reducionista que caracteriza as políticas de pessoal dos entes e sua evidente incapacidade para reconverter ou realocar pessoal em função das necessidades próprias da atividade substantiva, que devem desenvolver, tendem a descaraterizar seu perfil profissional.

Ao final de 1997, dezenas de empregados de FEMESA, a maioria deles engenheiros que trabalhavam em comissão na CNRT, foram confrontados com a opção de serem demitidos ou alocados a tarefas de controladores de chão do privatizado Ferrocarril Roca. Pelo acordo com os concessionários, os salários desse pessoal são pagos pelo Governo. A proposta que consistia em pagar a esses servidores $\$ 300$ por mês, em vez dos \$ 1700 recebidos até então, não motivou, naturalmente, a ninguém.

Os possíveis déficits nesta matéria não residem, aparentemente, na falta de capacitação para o exercício das tarefas ${ }^{31}$, apesar de que, em certos casos, como na CNRT, a imprensa tem denunciado que vários cargos-chave de nível gerencial têm sido ocupados por pessoas que não têm a idoneidade requerida para seu desempenho. Acreditamos que existam outras características das políticas de pessoal que possam resultar mais problemáticas.

Em primeiro lugar, ao estar enquadrados dentro da Lei de Contratos de Trabalho, na maioria dos casos, os funcionários não gozam de estabilidade em seus cargos. Essa política, que pode ter sido imaginada como uma forma de evitar os problemas de estabilidade dos funcionários, característicos da função pública, não parece ser conveniente no caso de funcionários que, face à ameaça de demissão, poderiam ver restringida sua liberdade de ação no exercício do controle.

Por outro lado, trata-se de funcionários que em boa parte vêm das ex-empresas públicas ou que desempenharam um papel importante nos processos de privatização. Ambas as situações poderiam condicionar suas atitudes em relação às novas tarefas que devem cumprir. Neste sentido, destaca-se a atitude pouco favorável a receber as demandas dos usuários, por considerar que se trata de questões menores. Esse comportamento, coerente com os procedimentos vigentes para realizar reclamações que mencionamos acima, revela uma desvalorização dos agentes mais fracos do esquema regulatório e contraria os esforços por incluir o ponto de vista dos usuários que caracterizam as diversas tentativas renovadoras da administração pública. 


\section{Conclusões}

A principal conclusão decorrente do presente trabalho é que os entes criados pelo governo argentino para regular os serviços públicos privatizados apresentam importantes déficits de capacidade institucional para levar a cabo sua missão com o alcance e profundidade que exige essa tarefa, sobretudo em vista da importância de se proteger o interesse público envolvido e o dos usuários.

Em termos ideais, uma regulação eficaz supõe preservar o funcionamento de regras de mercado que, ao mesmo tempo, evitem os efeitos indesejados da existência de monopólios, desacelerem a concentração da renda, promovam uma maior justiça distributiva e estimulem o crescimento da economia. Pode deduzir-se a medida do esforço adicional requerido para que a regulação cumpra esses objetivos, com base em alguns indicadores-chave acerca do grau em que se alcançaram ou não tais objetivos. Poderia afirmar-se, nesse sentido, que os DCI (Déficit de Capacidade Institucional) serão tão mais graves quanto mais negativos sejam os valores desses indicadores-chave.

Um recente estudo financiado pelo Banco Mundial (Chisari, Estache e Romero, 1997) analisa o impacto das privatizações sobre a eqüidade — baseando-se em um modelo que contempla duas opções diferenciadas pela suposição de preços flexíveis e de preços fixos dos serviços ${ }^{32}$. Esse estudo demonstra que, se as regulações e controles funcionassem corretamente, as empresas privatizadas deveriam transferir aos usuários quase 1 milhão de dólares, o qual equivale a um "sobre-preço" de $16 \%$ sobre o consumo desses usuários. A porcentagem chega a $20 \%$ quando a estimativa efetua-se para os usuários de menor renda relativa. Segundo os autores "isso demonstra por que os operadores privados têm um grande incentivo a disputar qualquer decisão dos regulatórios que os force a compartilhar suas rendas extraordinárias com o restante da economia".

O estudo conclui assinalando que "quando as regulações não são efetivas, os lucros da privatização traduzem-se em rendas extraordinárias para os mais ricos, que são os proprietários majoritários do capital nas empresas de serviços públicos". E adverte: "se não existir uma boa regulação, e se não se conseguir que os aumentos de produtividade se traduzam em queda de preços para os usuários, então os lucros se concentram nos setores mais altos".

Outro estudo (Aspiazu, 1997) demonstra que, das 50 empresas argentinas que obtiveram maior rentabilidade em 1995, 35 eram empresas vinculadas aos processos de privatização de serviços públicos. A rentabilidade dessas empresas representou $60 \%$ da obtida em conjunto pelas 200 maiores empresas nesse ano. Esses elevados lucros estiveram 
associados às favoráveis condições criadas pelos marcos regulatórios e à relativa arbitrariedade na fixação de preços, com independência em relação ao ciclo econômico.

Nem a ação dos entes regulatórios, nem a voz da sociedade têm sido, até agora, capazes de deter esse simultâneo processo de monopolização indesejável, de concentração crescente e de desigualdade cada vez mais profunda. As interrupções de estradas para frear o incremento do valor dos pedágios; os conflitos suscitados com os usuários em relação à questionada mudança das tarifas telefônicas; os protestos produzidos devido aos aumentos nos serviços de água, têm sido insuficientes para deter a ilimitada voracidade das empresas.

A menos de dois anos da finalização de seu mandato, o Governo está renegociando de forma ativa alguns dos contratos oportunamente assinados com as empresas concessionárias no marco da privatização. O resultado previsível é uma flexibilização das obrigações de investimento que ficariam mais sujeitas às próprias necessidades empresariais, acompanhadas de consideráveis aumentos nas tarifas que se destinariam a financiar esses investimentos. Telefones, trens, rotas concedidas mediante o pagamento de pedágio, água e esgotos subterrâneos integram a lista dos serviços que os concessionários esperam prestar sob novas condições. Aparentemente, a pressa deve-se, em parte, à possível limitação da margem de discricionariedade que se produziria no caso do Congresso Nacional adquirir um papel mais significativo no esquema de controle dos serviços ${ }^{33}$.

Ainda que as principais referências políticas dos diversos partidos têm manifestado que não haverá retorno nas privatizações, isso não equivale a garantir que se manterá, no vencimento, a titularidade das atuais concessões. Em um ano sem eleições, as condições para essa renegociação podem resultar propícias para o Governo, já que os possíveis custos políticos seriam atenuados. Não obstante, o prematuro lançamento da campanha eleitoral poderia converter o tema em uma das questões centrais do debate político que se aproxima.

Uma característica comum dos contratos que se estão renegociando é o aumento dos preços dos serviços para os usuários. Argumenta-se a necessidade de fazer obras que, se não fossem realizadas, poderiam afetar a prestação ou a qualidade do serviço, mas se desconhece se isso redundará, no momento certo, em uma queda das tarifas.

Em qualquer caso, uma coisa é certa: a capacidade atual dos entes regulatórios não permite prognosticar que, dado este âmbito institucional, possam deter-se (menos ainda reverter-se) as tendências em direção a uma crescente concentração e apropriação indevida de rendas por parte das empresas prestadoras de serviços públicos. Frente a tanta responsabilidade e à evidente debilidade operativa dos entes, "alguém" deveria assumir o papel de "custodiar os custódios". 
Como temos tentado demonstrar, a tarefa não se reduz simplesmente a dotar os entes de organização, pessoal, recursos e tecnologias necessárias, por mais imprescindível que isso seja. A superação dos DCI encontra seu limite quando o custo marginal do investimento na melhoria da gestão resulta superior ao benefício marginal resultante de uma regulação mais eficaz. Isso ocorre quando esse investimento é compensado pela contínua vigência das regras de jogo que governam os vínculos entre empresas, entes e usuários, assim como das redes interinstitucionais pelas quais se canalizam tais relações. Com base nisso, remover esses condicionamentos "externos" à gestão própria dos entes regulatórios é, também, parte inseparável dos esforços de fortalecimento institucional.

Até agora, as evidências de captura dos entes pelas empresas (que não parecem ser alheias às políticas e comportamentos governamentais) sugeririam que a determinação necessária não surgirá espontaneamente nem das entidades regulatórias, nem do atual Poder Executivo. Uma mudança de orientação poderia vir do esforço conjunto de um Poder Legislativo com maior protagonismo neste campo ${ }^{34}$, de uma Auditoria Geral da Nação menos limitada na sua capacidade de intervenção ${ }^{35}$, de um Poder Judicial não condicionado pelas tomadas de posição do Executivo e da reclamação sistemática (espontânea, institucionalizada ou mediada) por uma cidadania cada vez mais comprometida com a recuperação da cena pública e a promoção dos interesses igualmente públicos que nela são defendidos.

\section{| Notas}

${ }^{1}$ Inesperadamente, faz muitos anos que a China Popular iniciou esse processo: modificar o papel do Estado, suprimir organismos e reduzir a folha de pessoal, chamando-as "três fixações" ou o princípio da decisão tripla.

2 Por exemplo, não iniciaremos uma discussão do conceito de regulação, as formas em que se estabelece, seus alcances ou seus sujeitos. Dentre os trabalhos que abordam esses aspectos, cabe citar os de Majone e La Spina (1993), Mitnick (1989) e Reagan (1987).

3 Podem ser consultados os trabalhos de Bitrán e Saavedra (1993), Coloma e Gerchunoff (1992), Thury Cornejo (1995), Ariño Ortiz (1995), Vickers e Yarrow (1992), Urbiztondo, Artana e Navajas (1997) que, dentre muitos outros, abordam amplamente os aspectos técnicos da regulação.

4 O conceito de capacidade institucional, utilizado no trabalho, se ajusta à definição sugerida por Tobelem (1992). As variáveis propostas por es se autor para analisar os "déficits de capacidade institucional" do sistema de regulação estatal serão utilizadas para fins de identificação e avaliação das possíveis fontes desses déficits. 
5 A teoria econômica reconhece três tipos de situações em que o mercado costuma falhar: o caráter indivisível dos bens, a presença de externalidades ou a prestação em condições de monopólio natural que justificam a intervenção estatal. Baseia-se na suposição de que o mercado é o regulador ótimo e, em conseqüência, quando existem condições que impedem seu funcionamento normal, requer-se a presença de um regulador externo para sanar essas situações mediante "a criação de condições semelhantes às do mercado..." (Lahera, 1994). Trata-se de entregar incentivos capazes de promover a eficiência na alocação de recursos, limitando ao mínimo ou eliminando a margem para a discricionariedade na fixação de preços. Em outros termos, o Estado deveria "obrigar os titulares e diretivos das empresas prestadoras a atuar com a mesma eficácia com que deveriam se atuassem no mercado" (Ariño Ortiz, 1995).

Embora teoricamente se aceite que a concorrência induz à busca da eficiência, reconhece-se que o bom funcionamento do mercado não garante a eqüidade (Bitrán e Saavedra, 1993). Perspectivas menos ortodoxas (e também menos desenvolvidas) começam a levar em conta os efeitos da lógica mercantil sobre a saúde, o ambiente, a segurança dos trabalhadores, os interesses dos consumidores e a necessidade de adotar medidas anti-discriminatórias ou de garantia dos direitos de cidadania e a proteção de terceiros alheios à relação de intercâmbio (Majone e La Spina, 1993).

Entre as situações de maior repercussão pública cabe mencionar as dificuldades em matéria dos critérios empresariais no fornecimento dos serviços aos setores de menores recursos, acidentes cujas responsabilidades nunca foram esclarecidas, e um conjunto de projetos apresentados no Congresso para colocar os organismos de regulação sob controle legislativo, que se formularam no marco de fortes confrontos entre legisladores do partido governante e o ex-Ministro de Economia Domingo Cavallo, que havia levado adiante as privatizações e sob cuja órbita haviam ficado os organismos regulatórios.

7 Prova disso é a preocupação do Banco Mundial (1997) para que os países adotassem posturas reguladoras, capazes de responder, em cada caso, às demandas da economia e da sociedade, assim como à capacidade institucional existente para levá-la a cabo. No seu relatório sobre o Desenvolvimento Mundial de 1997, afirma-se que "a atenção à adequação entre o papel do Estado e sua capacidade institucional ajuda a reconciliar algumas fórmulas para a ação do Estado aparentemente conflitantes".

Exemplo desta ausência é a criação puramente formal do ente que deve encarregar-se de regular os aeroportos recém-privatizados. Em 30 de dezembro de 1997, uma sentença judicial ordenava suspender os trâmites de privatização dos aeroportos até que fosse criado o organismo de regulação correspondente. No mesmo dia foi publicado o decreto de criação do Organismo Regulador do Sistema Nacional de Aeroportos. A sanção desse decreto permitiu iniciar a abertura das ofertas econômicas dos consórcios que haviam sido qualificados para concorrer pela concessão (Diario La Nación 31/12/97 e 8/1/98).

9 Somos conscientes de que a institucionalidade regulatória é apenas uma das dimensões a serem consideradas para esses efeitos. As modificações ocorridas nos planos das relações de poder e da redistribuição abrangem um conjunto muito amplo de aspectos da vida social e não podem dissociar-se dos processos globais de ajuste estrutural. Porém, a opção por alguns dos possíveis objetivos a serem alcançados mediante a regulação de serviços públicos, a escolha de um ou outro esquema de regulação e a qualidade de seu funcionamento, podem aliviar ou aumentar esses efeitos.

10 A dupla qualidade/preço do serviço poderia ser considerada como ponto de articulação entre esses três vértices. Entre as dimensões a serem consideradas para a definição da qualidade dos serviços se contam a continuidade e a confiabilidade do fornecimento, a rapidez e eficácia dos consertos de possíveis falhas, a segurança, a clareza e abrangência da informação acerca das condições de prestação que deveriam ser normatizadas em 
função das características de cada serviço; contempladas na prestação dos serviços por parte das empresas e garantidas pela ação regulatória do Estado.

11 Essa opção coincide com a sugestão do Banco Mundial (1997) de reconciliar objetivos regulatórios e capacidades institucionais, propondo objetivos mais ou menos ambiciosos em função da análise das forças e fragilidades existentes.

12 Entrevista ao Ministro Dromi, Diario Página 12, 3/5/90.

13 Embora a abrangência dos marcos regulatórios contribua com transparência e limite, a margem de arbitrariedade também demanda maiores capacidades institucionais de gestão. Por um lado, a elaboração e aplicação de normas mais minuciosas representa um maior custo de regulação e, por outro lado, uma normatização mais detalhada é, geralmente, mais inflexível face a situações não previstas. Nesse sentido, Vickers e Yarrow (1991) assinalam que a especificação dos contratos de concessão se torna também válida para os marcos regulatórios. Se contém excessivos detalhes podem se tornar difíceis de redigir ou aplicar; se, pelo contrário, exige-se determinada prestação, quaisquer que sejam as circunstâncias, podem se tornar inviáveis, sobretudo a longo prazo. Se são "incompletos", requerem esforços permanentes de administração e supervisão e abrem maiores possibilidades, tanto à discricionariedade administrativa, quanto à necessidade de maior negociação entre regulador e regulado. Neste último caso, quanto maior a posição de recursos de poder e a capacidade de pressão do regulado, maiores são as oportunidades de captura do regulador por parte do regulado, em detrimento dos usuários dos serviços.

14 No primeiro caso, o organismo está envolvido na aplicação de medidas previstas nos contratos de concessão: i.e. a aplicação da taxa por infra-estrutura aos novos usuários e o faturamento em bloco aos imóveis em propriedade horizontal, mencionados em nota anterior e cuja resolução foi além do ETOSS. Por sua vez, a instabilidade que caraterizou a CNT teve grande repercussão pública: um ano após ter sido criada, se enquadrou na órbita da Subsecretaria de Comunicações do Ministério de Economia, cuja criação foi posterior à da própria Comissão. Mais tarde, no início de 1992, foi objeto de intervenção, situação que durou quase dois anos. Uma vez normalizada, a oposição de alguns de seus diretores aos critérios impostos pelo Poder Executivo para a adequação das tarifas, descencadeou uma nova intervenção em 1995, que a vinculou mais estreitamente à Subsecretaria de Comunicações. Como resultado de disputas políticas que estão além da Comissão, a subsecretaria se transformou, em 1996, em secretaria e passou da órbita do Ministério da Economia para o âmbito da Presidência da República (Urbiztondo, Artana e Navajas, 1997). Uma vez neste marco, transformou-se na CNC, encarregada da regulação de um conjunto mais amplo e heterogêneo de atividades.

15 Ver nota 1.

16 O conceito de captura faz referência à possibilidade de controle das decisões da agência reguladora por parte das empresas reguladas que têm contatos freqüentes e contam com recursos para condicionar os reguladores a serem receptivos a seus argumentos.

17 Não desconhecemos, no entanto, que a conveniência ou inconveniência deste tipo de mecanismo é matéria de discussão jurídica e que muitos destes projetos estão inscritos no aumento de disputas no seio do governo incluindo, entre outras questões, a forma em que se levaram a cabo as privatizações e a luta pelo controle de uma área muito sensível do Estado, como é a regulação dos serviços públicos.

18 Não é possível ignorar que a unificação, prevista pelo decreto 660/96 e concretizada em fins de 1996, respondeu a uma reorganização da administração pública impulsionada por restrições orçamentárias, que prevaleceram em relação aos critérios técnicos justificadores da conveniência desta unificação. De toda forma, esse esquema poderia trazer resultados positivos só na medida em que fosse possível integrar a gestão do controle dos diversos meios de transporte, o que até o momento não tem ocorrido. 
19 De acordo com o art. 21 do decreto 999/92, criou-se uma Comissão Assessora ad

Honorem cujo objetivo é oferecer assistência ao corpo diretivo do ente, em questões de caráter econômico-financeiro, legal e científico, relacionadas com a concessão, e cuja integração cabe à diretoria do ente. A Comissão Assessora teve uma breve experiência de funcionamento, levando-se em consideração que, desde o momento de sua criação em agosto de 1993, foi convocada apenas para participar na discussão da proposta de Regulamento do Usuário apresentada pela empresa Águas Argentinas.

20 Obriga as empresas a informar aos usuários sobre as condições da prestação e os direitos e obrigações de ambas as partes. Também fixa prazos para a resolução de reclamações ou recebimento de faturas que implicam em maiores garantias que surgem da normatização regulatória. São especialmente importantes os pontos que se referem à suposição de erro de faturamento (quando o faturamento de um período excede em $75 \%$ da média dos dois anos anteriores, presume-se que existe erro e se permite ao usuário pagar unicamente o valor médio), a indenização por reclamações de montantes incorretos ou faturas já pagas e a fixação de tetos para as taxas por pagamento fora do vencimento, que são consideravemente menores que os impostos pagos por algumas empresas.

21 Esta divisão territorial determina que muitos usuários deveriam deslocar-se para outra província para realizar um trâmite no ente. Como exemplo, cabe mencionar que o Escritório Regional Noroeste, sediado na cidade de Salta, atende as províncias de Santiago del Estero, Tucumán, Salta e Jujuy. Todos os usuários da região metropolitana, do norte da província de Buenos Aires e da região da província da pampa são atendidos na sede central da Capital Federal.

22 Por exemplo, a aprovação dos planos de investimento que executam as empresas concessionárias com subvenção estatal, começou a ser encaminhada a técnicos vinculados com a nova direção da CNRT, tirando de fato essa atribuição do Gerente de Concessões Ferroviárias. Essa pessoa pertencia à equipe privatizadora dos trens urbanos na gestão Cavallo. A Gerência administra os quase 200 milhões de dólares por ano que o Estado destina para cobrir o déficit operacional e o plano de investimentos dos adjudicatários.

23 A fixação da renda do ETOSS como sendo uma alíquota da renda da empresa regulada permitiu um incremento de mais de $40 \%$ de seus recursos em dois anos, mas esse tipo de mecanismo aumenta o risco de captura por parte de Águas Argentinas (Urbiztondo, Artana e Navajas, 1997).

24 Claro exemplo desta situação é o corte que sofreu o ENRE, cuja estimativa orçamentária para 1996 era de $\$ 16.598 .486$ e foi reduzida pela Secretaria da Fazenda para \$ 9.321.010. Em um relatório elaborado pela instituição, coloca-se que "não parece correto que a Sec. de Fazenda modifique o orçamento elaborado pela diretoria de um ente autárquico (...) menos ainda quando não se trata de recursos originados no Tesouro Nacional".

25 Revista Mercado, abril de 1994.

26 O próprio titular do organismo manifestava que "com os fundos que nos deixaram é praticamente impossível levar adiante as tarefas de controle..." (Diario Clarín, 5/1/95).

27 Além do pessoal fixo, a dotação da CNRT se compõe, em grande parte, de pessoal contratado cujos contratos não foram renovados a partir da sanção do orçamento de 98 . Nas principais gerências da CNRT, o orçamento designado aos contratos se reduziu pela metade. O organismo viu-se obrigado a desfazer-se de especialistas que elaboram os inventários dos bens ferroviários entregues em concessão (cuja propriedade é retida pelo Estado). Os cargos de muitos técnicos responsáveis por inspecionar o estado dos veículos de transporte, assim como a relação entre tarifas e custos, têm sido suprimidos, o que explica por que os inquéritos administrativos por denúncias ou infrações contra as linhas de transporte continuam acumulando-se sem resposta. Recentemente, 
a CNRT transferiu o responsável de supervisionar os programas de investimentos dos trens urbanos financiados pelo Estado e representam montantes multimilionários. Tampouco renovou o contrato do chefe da auditoria contábil, encarregado da revisão dos balanços dessas concessões. $\mathrm{O}$ último fato que produziu comoção na CNRT foi a decisão de liquidar definitivamente a FEMESA (o ente residual dos trens urbanos) privando-o de orçamento. Isto implicou na drástica diminuição de pessoal do órgão regulador, que em grande parte se compõe de pessoal de FEMESA em comissão.

28 Resolução no 67, 3/4/96.

29 Segundo o decreto 2218/94, que estabelece a estrutura orgânica da Comissão, a Gerência de Segurança deveria se encarregar de elaborar e executar esses programas.

30 O exercício efetivo do controle não depende, entretanto, da mera posse da informação, mas do conjunto de fatores que temos analisado. Um organismo de regulação poderia contar com um conjunto importante de informações relevantes e tomar decisões em função dos interesses empresariais no caso de estar capturado. Não obstante, o caso contrário é improvável, o que indica a importância de se contar com mecanismos que permitam obter essa informação.

31 Não obstante, a avaliação dos déficits em matéria de capacitação para as tarefas específicas que desempenham os funcionários requereria uma análise das características de cada posto e da capacitação de quem o ocupa, o que ultrapassa os limites deste trabalho.

32 Que corresponderiam à regulação efetiva e ineficaz, respectivamente.

33 Não é casual que a ameaça de uma futura tutela legislativa tenha precipitado a criação de uma câmara patronal das poderosas empresas concessionárias, nos momentos em que a maioria dos contratos de adjudicação começaram a renegociar-se. No final de 1997, as telefônicas, Edenor, Edesur, Metrogás, Gás Natural e Metrovías formaram a Associação de Empresas de Serviços Públicos Argentinos, integrada à Câmara Argentina de Comércio.

34 De acordo com uma recente compilação realizada pela Fundação Conselho para o Projeto Argentino, foram apresentados ao Congresso quinze projetos de lei para reformular o sistema de controle dos serviços públicos. A maioria dos projetos propõe colocar todos os entes sob um órgão superior (conhecido como superente) que, segundo algumas propostas, poderia integrar-se com os próprios legisladores. A investida parlamentar é liderada por Deputados, e especialmente, por legisladores do partido oficial da Província de Buenos Aires, o que inclui a iniciativa dentro da luta partidária interna por quotas de poder, visando as próximas eleições. À exceção da Comissão Nacional de Comunicações, que controla os serviços telefônicos e postais e funciona na órbita do Secretário de Comunicações, o restante dos entes nacionais dependem do Ministério da Economia. Corresponde a esse Ministério fiscalizar a obediência dos contratos e autorizar mudanças tarifárias, tarefa que participam os entes regulatórios, cuja nomeação também lhes compete. Se prosperassem as mudanças impulsadas pelo Congresso, o Ministério da Economia perderia essas faculdades.

35 Embora a Aliança constituída pela UCR, o FREPASO e outros partidos políticos menores insinuou reiteradamente sua intenção de aumentar os controles sobre as empresas privatizadas, os legisladores do FREPASO tendem a limitar suas propostas ao fortalecimento da Auditoria Geral da Nação. Esse órgão apresenta seus relatórios ao Congresso por meio da Comissão Revisora de Contas, instância na qual, geralmente, são arquivados, sem originar outros desdobramentos. 


\section{| Referências bibliográficas}

Aspiazu, D. (1997), Elite empresarial en la Argentina. Tercerización, Centralización del Capital, Privatización y Beneficio Extraordinario, Proyecto Secyt-Conicet (Documento de Trabajo n. 2 del Proyecto Privatización y Regulación en la Economia Argentina).

Aspiazu, D. e Vispo, A. (1994), "Algunas enseñanzas de las privatizaciones en Argentina". Revista de la CEPAL. n. 54, Santiago de Chile, dezembro.

Banco Mundial. (1997), El Estado en un mundo en transformación. Informe sobre el Desarrollo Mundial. Washington.

Bitran, E. e Saavedra, E. (1993), "Promoción de la competencia y regulación de los monopolios naturales". En Lahera, E. Cómo mejorar la gestión pública. Cieplan, Flacso, Foro 90, Santiago de Chile.

Chisari, O. Estache, A. e Romero, C. (1997), Winners and Losers from Utility Privatization in Argentina. Lessons from a General Equilibrium Model. The World Bank, Policy Research Department. Finance and Private Sector Development Division. Policy Research, Working paper 1824.

Gerchunoff, P. e M achineA, J. (1995), "Un ensayo sobre la política económica después de la estabilización" . En Bustos, P. (comp.) Más allá de la estabilidad. Argentina en época de la Globalización y la Regionalización. Buenos Aires: Fundación Friedrich Ebert.

Hill, A. e Abdala, M. (1993), Regulation, Institutions, and Commitment. Privatization and Regulation in the Argentine Telecommunications Sector. The World Bank, Policy Research Department. Finance and Private Sector Development Division. Policy Research, Working paper 1216.

Hirschman, A. (1964), Estudios sobre política económica en América Latina (en ruta hacia el progreso). Buenos Aires: Aguilar.

LAHERA, E. (1994), "Nuevas orientaciones para la gestión pública". Revista de la CEPAL, n. 52, Santiago de Chile, abril.

Lopez, A. (1997), Regulacion y control de la calidad de los servicios publicos privatizados, Tesis de la Maestría en Administración Pública, Facultad de Ciencias Económicas, UBA, mimeo.

M aiRAl. (1993), "La ideología del servicio público", Revista de Derecho Administrativo, año 5, n. 14, Buenos Aires, setembro-dezembro.

Majone e La Spina. (1993), "El Estado regulador”. En Gestión y Política Pública. v. II n. 2, Centro de Investigaciones y Docencia Económica, México, julho-dezembro.

M ттNICK, B. (1989), La economía política de la regulación. Fondo de Cultura Económica, México.

Ortiz, G. A. (1995), Teoría y práctica de la regulación para la competencia. (Hacia un nuevo concepto de Servicio Público) Mimeo. En Seminário sobre Regulación de los Servicios Públicos Privatizados, Buenos Aires, Universidade de Belgrano, 5 a 7 de setembro.

Reagan, M. (1987), Regulation. The politics of policy. Little, Brown and Company, Boston.

Rodriguez, J. (1996), "La tarea de reforma constituye una actividad permanente hacia una administración más eficiente”. Entrevista em Aportes para el Estado y la Administración Gubernamental. año 3. n. 6. Otoño, Buenos Aires.

Thury Cornejo, V. (1995), "Fundamentos y límites de la potestad sancionatoria de los entes reguladores de servicios públicos". Revista de la Administración Pública. n. 207. 
Toвelem, A. (1992), Instutional Capacity Analysis and Development System (ICADS). Public Sector Management Division, Technical Department Latin America and the Caribbean Region of the World Bank. LATPS Occasional Paper Series n. 9.

Torre, J. e Gerchunoff, P. (1988), "El papel del Estado". Revista IDEA, Buenos Aires, maio.

Urbiztondo, S. Artana, D. e Navajas, F. (1997), La autonomía de los entes reguladores. FIEL, Proyecto Red de Centros del Banco Interamericano de Desarrollo. Mimeo.

Vickers, J. e Yarrow, G. (1991), Un análisis económico de la privatización. Fondo de Cultura Económica, México. 


\title{
A capacidade de regulação estatal na Argentina
}

\section{Oscar Oszlak e Ruth Felder}

O trabalho analisa os déficits de capacidade institucional dos entes do governo argentino responsáveis pela regulamentação do fornecimento de serviços públicos oferecidos por entidades privadas, após o maciço processo de privatização que aconteceu nos anos 90. Oferece uma interpretação dos desafios institucionais que implica substituir as funções tradicionais de produção, financiamento e prestação de serviços do setor público por funções de regulamentação e controle.

O objetivo principal do artigo é estabelecer quais são as relações requeridas entre responsabilidades reguladoras e capacidades institucionais disponíveis. Isto implica um exame sistemático de seis tipos de déficits que podem afetar o desempenho dos entes reguladores: 1) as regras de jogo que governam as relações entre agentes envolvidos no processo regulador (p. ex, agências, fornecedores e cidadãos); 2) a natureza das redes inter-institucionais estabelecidas entre os agentes; 3 ) as conciliações estruturais e funcionais criadas para desempenhar funções reguladoras; 4) as políticas de incentivos e sanções fixadas para os entes reguladores desempenhem seu papel; 5) os recursos materiais e humanos disponíveis; e 6) as capacidades individuais requeridas para cumprir com as funções de uma forma eficaz.

O trabalho chega à conclusão de que os entes reguladores criados pelo governo argentino apresentam deficiências significativas no tocante à capacidade institucional para cumprir sua missão com o alcance e profundidade necessários, especialmente tendo em conta que nisto se encontram comprometidos o interesse público e o bem-estar dos consumidores.

\section{La capacidad de regulación estatal en la Argentina Oscar Oszlak y Ruth Felder}

El trabajo analiza los déficit de capacidad institucional de las agencias del gobierno argentino responsables de regular la provisión de servicios públicos brindados por firmas privadas, luego del masivo proceso de privatización que tuvo lugar en los años 90. Ofrece una interpretación de los desafíos institucionales que implica reemplazar las funciones tradicionales de producción, financiamiento y prestación del sector público por funciones de regulación y control.

El objetivo principal del artículo es establecer cuáles son las relaciones requeridas entre responsabilidades regulatorias y capacidades institucionales disponibles. Ello implica un examen sistemático de seis tipos de déficit que pueden afectar el desempeño de las agencias regulatorias: 1) las reglas de juego que gobiernan las relaciones entre los actores involucrados en el proceso regulatorio (v.g. agencias, prestadores y ciudadanos); 2) la naturaleza de las redes inter-institucionales establecidas entre esos actores; 3 ) los arreglos estructurales y funcionales creados para desempeñar funciones regulatorias; 4) las políticas de incentivos y sanciones fijadas a las agencias regulatorias para desempeñar su rol; 5) los recursos materiales y humanos disponibles; y 6) las capacidades individuales requeridas para cumplir con las funciones de una manera eficaz.

El trabajo arriba a la conclusión de que las agencias regulatorias creadas por el gobierno argentino presentan significativas deficiencias en cuanto a la capacidad institucional para cumplir su misión con el alcance y profundidad necesarios, especialmente teniendo en cuenta que en ésto se hallan comprometidos el interés público y el bienestar de los consumidores.

\author{
Oscar Ozlak, \\ doutor em \\ Ciências Políticas \\ pela Universidade \\ de Berkeley. \\ Doutor em \\ Ciências Econô- \\ micas, diretor \\ do programa de \\ mestrado em \\ Administração \\ Pública e pesqui- \\ sador do Conse- \\ lho Nacional \\ de Pesquisas \\ Científicas e \\ Técnicas da \\ Universidade de \\ Buenos Aires. \\ Ruth Felder, \\ mestre em \\ Administração \\ Pública, licen- \\ ciada em \\ Ciências Polí- \\ ticas, professora \\ assistente da \\ Faculdade \\ de Ciências \\ Econômicas na \\ Universidade de \\ Buenos Aires
}




\section{State regulatory capacity in Argentina}

\section{Oscar Oszlak and Ruth Felder}

The paper deals with the institutional capacity deficit exhibited by those agencies or the Argentine government in charge with regulating the provision of public services by private firms, following the massive privatizacion process that took place during the 90's. It offers an interpretation of the institutional challenges involved in replacing the traditional production, financing and delivery functions of the public service by regulatory and control functions.

The main concern of the paper is to find out what are the required relationships between regulatory responsibilities and available institutional capacity. This implies a systematic examination of six types of deficit that may affect the performance of the regulatory agencies: 1 ) the rules of the game governing the relationships among the actors involved in the regulatory process (i.e. agencies, providers and citizens); 2 ) the nature of the inter-institutional networks established among those actors; 3 ) the structural and functional arrangements created to perform regulatory functions; 4) the policies of incentives and sanctions established for regulatory agents to perform their role; 5) the material and human resources available; and 6) the individual capacities requiered to render services in an effective way.

The paper concludes that the regulatory agencies created by the Argentine government exhibit substantial shortcomings in institutional capacity to carry out their mission with the necessary scope and depth, more so when the public interest and consumers' wellbeing are at stake. 